\title{
A Horticultural Student Recruitment System that Works
}

\author{
Norman F. Childers, Eric Bish, and Donald Merhaut \\ Horticultural Sciences Department, University of Florida, Gainesville, FL 32611
}

Enrollment of a substantial number of horticultural undergraduate students is important for maintaining a viable horticultural department. Administrators and industry support departments with good class enrollments and active alumni. With the current low undergraduate enrollments in horticulture across the country and low public budgets, many horticulture departments are losing faculty and several are disappearing into other departmental combinations.

The senior author, for some 60 years, has tried many ideas for recruiting horticultural students. Each has been effective to a limited extent, often involving much time in contacting Vo-Ag and high school career advisors, making movies and slides, printing and distributing brochures, and designing and transporting displays to meetings. These continuing efforts are worthwhile and needed. However, we have found it easier, perhaps less expensive, and more effective to recruit students already on the campus. On college campuses, there always has been a wealth of students still undecided on a major or mirror, even in their senior year. The problem is to find a way to attract these students to a stimulating experience in horticulture and, at the same time, gain administrative credit for more undergraduates in departmental classes.

We developed a 1-h mini "snack" course, Growing Fruits for Fun and Profit, first taught only at noon in 1991. (The original idea and title of this course came from Emeritus Professor Paul Eck of Rutgers Univ., New Brunswick, N.J.) The course is now divided into two sections: one taught at noon in the horticulture building and a larger section taught in a more centrally located building at 4:00 PM on the same day. This class has grown in popularity, increasing from 34 students in 1991 to 74 in 1992,165 in 1993, and 270 in 1994. Prospects are good for further increases in the future.

The noon snack, which includes fruit, has been a unique drawing card for students. Bulletin board posters distributed across the campus before registration also have been an effective recruiting tool. But reproducing the poster in the daily campus newspaper (Fig. 1) as registration begins probably has been most effective. Including a face in the advertise-

Received for publication 29 June 1993. Accepted for publication 17 July 1993. Viewpoints are published in HortScience to provide members of the American Society for Horticultural Science an opportunity to share their experiences and comments on matters of concern to horticulturists. These are not statements of official Society policy, nor do they necessarily reflect the views of a majority of the Society's members. The cost of publishing this paper was defrayed in part by the payment of page charges. Under postal regulations, this paper therefore must be hereby marked advertisement solely to indicate this fact. ment draws more attention than just text. Advertising a college course in a newspaper is rare; the problem is finding private money to finance it ( $\$ 150$ to $\$ 180)$, since state money cannot be used. After 1 or 2 years of this unique course, one hears students discussing it in dormitories and registration lines. Students come to this course from diverse majors: law, medicine, athletics, history, languages and communication, and a sizable number from agriculture.

Each 50-min lecture covers an important fruit grown in Florida. Resident teaching and extension faculty cooperate in giving lectures in their specialized fields. The following subjects are covered briefly for each fruit: botanical names, importance to the state, cultivars, flowering, fruiting and growth habits, anatomy (fruit is dissected), climate and soils, planting, training, irrigation, pruning, pollination, fruit thinning, important pests and control, harvesting, storage, and marketing. This is a big order, but it can be done. One key lecture is devoted to "U-pick" operations and direct marketing. Another covers fruit juice and wine processing. Information on production costs, when available; leaflets; and other handouts are given to students when they enter the classroom. Lecture rooms are held vacant $1 \mathrm{~h}$ before class begins so that the instructor has time to write information on the blackboard. Color slides and an array of props are used, such as flowering branches, a nursery tree, and a sawed-off 6-year-old bearing dwarf tree, to demonstrate planting, training, pruning, fruiting, pest control equipment, and pruning tools, including an operable chain saw for excitement. It is a different show, with items not seen in botany or biology classes; what the students see and learn can be useful to them regardless of their major.

On the first day of class, students receive a handout that describes course management and grading. A return handout also is circulated for students to record their campus and home addresses, phone numbers, major, and why they are taking the course. This information has been useful later. Color photographs of the classes are taken, and a print, along with the final grade, is mailed to the students' homes on course completion. Also included is a friendly letter telling the students to show the print to their children in 15 years so that they can see how it was when their parents went to college. The students' parents seem to look on this favorably, and some, through their children, tell us they are happy to see them learning to eat fruit. The senior author often greets students at the door, spends time with them after class, and writes phrases such as "Welcome back to horticulture" and "Have a good spring break" on the board. These gestures make them feel welcome.

A part-time graduate assistant and a parttime helper are provided by the department chairman to buy and prepare top-quality readyto-eat fruit (new cultivars are introduced, e.g., 'Gala' and 'Fuji' apples) and fruit juices, along

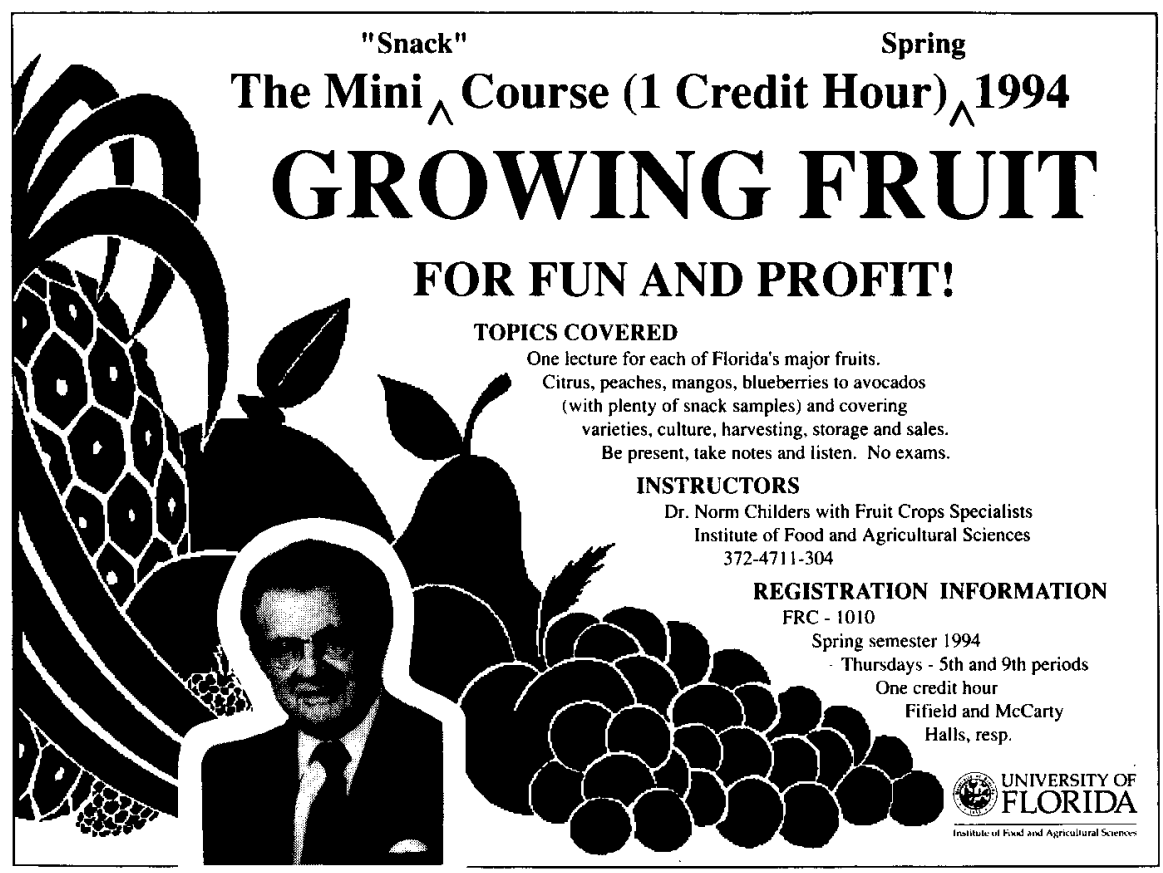

Fig. 1. An $8 \times 1$ l-inch poster (black letters on bright yellow background) is distributed to campus bulletin boards to promote the course. The poster also was reproduced in the campus newspaper (three columns wide) before class registration. This method is most effective. 
with various cookies and muffins. Fruit is ordered in advance from a local supermarket or distributor and stored at $\approx 15 \mathrm{C}$ in a walk-in refrigerator. A laboratory fee of $\$ 15$ provides about $\$ 1$ per student per lecture. The fee in our case can be used only for fruit and fruit juices. Private funds from the SHARE Foundation, gifts to agriculture from industry, are used for bakery foods, advertising, and serving materials. The one or two apples and cookies, a napkin, etc., are placed in small paper bags that the students pick up with a cup of fruit juice on entering the" classroom. Processed out-of-season fruits, such as sweet cherries, are served on divided plates.

There are no tests and no outside work. The most important component in grading is a neat notebook of brief, organized lecture notes and handouts. One absence is allowed; others require legitimate excuses. Notebooks are collected at the next to last lecture, graded, and returned at the final meeting, which is a tour of the department's orchard. In 1993, we included a lecture on vegetable gardening, and in 1994, we added a lecture on the basics of landscape design, which the students can use in their future homes.

This course has increased our majors in fruit and vegetable crops from one or two students to $\approx 40$ and promises further increases. Horticulture needs more top scholars and leaders. To achieve this, many undergraduates are needed. If students have not chosen a major as they enter a university, they seem to follow the crowd to the more popular departments, such as food and resource economics, microbiology and cell science (premedicine), and animal science (preveterinary), which have the largest followings. We hope this situation can be developed for horticulture.

To organize and manage this course, a thoroughly interested faculty member is needed with full administrative support. This faculty member must have a truly personal interest in students, must attract them, and enjoy taking the time to teach and work with them. Research and other departmental duties must be lessened to allow time to coordinate the project, give lectures, and ensure that the details of each lecture are well planned in advance and that the instructors, as well as the department chairperson, and their respective roles in the department are carefully introduced to the students.

In recent years, recruiting and teaching horticultural undergraduates has taken aback seat to "high-tech" research and seeking outside grant money. A gradual weakening and disappearance of horticultural departments is the result. We often hear "a better balance is needed between research and-teaching." Let us try to do something about undergraduate recruitment and teaching. 